National Marine

Fisheries Service

NOAA
Fishery Bulletin

ar established in 1881 \%
Spencer F. Baird

First U.S. Commissione of Fisheries and founder of Fishery Bulletin

\begin{abstract}
Understanding how species grow is critical for choosing appropriate fisheries management strategies. Sea cucumbers shrink during periods of aestivation and have naturally flaccid bodies that make measuring growth difficult. In this study, we obtained lengthfrequency data on Holothuria arguinensis, measuring undisturbed animals in situ, because it is one of the new target species of the NE Atlantic and Southwestern Mediterranean fisheries. Growth parameters were estimated for individuals inhabiting the Ria Formosa lagoon (Portugal). Length-frequency data were collected between November 2012 and March 2014 by using a visual census augmented with random sampling in 2014. To estimate the asymptotic length $\left(L_{\infty}\right)$ and growth coefficient $(K), 2$ different growth models were fitted to the length frequency data for 1198 sea cucumbers: the nonseasonal von Bertalanffy and Hoenig seasonal von Bertalanffy models. A $L_{\infty}$ of $69.9 \mathrm{~cm}$ and $K$ of 0.88 were estimated by using the Hoenig function for seasonal growth. The value of 1.0 obtained for the parameter $C$ of this function indicates reduction in growth during winter. The relatively high growth rate $(K)$ of this species may have important implications for its survival, mainly in environments where conditions cause biological stress and oceanic disturbances but may also increase its potential as a candidate for aquaculture.
\end{abstract}

Manuscript submitted 18 January 2017. Manuscript accepted 21 September 2017. Fish. Bull. 116:1-8 (2018).

Online publication date: 10 October 2017. doi: 10.7755/FB.116.1.1

The views and opinions expressed or implied in this article are those of the author (or authors) and do not necessarily reflect the position of the National Marine Fisheries Service, NOAA.

\title{
Estimation of growth parameters for the exploited sea cucumber Holothuria arguinensis from South Portugal
}

\author{
Julián Olaya-Restrepo ${ }^{1,2}$ \\ Karim Erzini1 \\ Mercedes González-Wangüemert (contact author) ${ }^{1}$ \\ Email address for contact author: mwanguemert@ualg.pt \\ 1 Centro de Ciências do Mar \\ Universidade do Algarve \\ Campus de Gambelas \\ 8005-139 Faro, Portugal \\ 2 Departamento de Zoologia \\ Setor de Ciências Biológicas \\ Universidade Federal do Paraná \\ Avenida Coronel Francisco H. dos Santos, 100 \\ 19020 Curitiba, Brazil
}

The economic value of sea cucumbers is well known and at least 66 species have been harvested in more than 70 countries (Purcell et al., 2012), but these fisheries usually follow a boom and bust pattern (Eriksson et al., 2012; Purcell et al., 2013; González-Wangüemert et al., 2014; González-Wangüemert et al., 2015). The rapid expansion of sea cucumber fisheries over the past several decades has overshadowed efforts to implement effective management, leading to overexploitation of sea cucumbers by the majority of fisheries worldwide (Purcell et al., 2013; González-Wangüemert et al., 2016). This inadequate management is primarily due to insufficient biological and ecological knowledge of target species (Lovatelli et al., 2004; Purcell, 2010). Knowledge of growth parameters not only is essential for conservation and management of a target species but also for reducing fishing pressure on wild populations. One common fisheries management measure, for example, has been the implementation of a minimum size at capture, which is species-specific and often based on size at first maturity (Bruckner, 2006; Purcell, 2010). This management measure is important because of its applicability in the field, and together with information on the time to reach maturity, can be used to implement seasonal closures, as well as be used in guidelines for rebuilding hatchery stocks.

Estimation of growth rates of sea cucumbers is difficult because of their ability to shrink (negative growth), their flaccid body, and their propensity to shed physical tags (Conand, 1983; Uthicke et al., 2004; Purcell et al., 2008). Until recently, external tagging methods have been unsuitable for estimating growth owing to biological factors such as evisceration, necrosis, skin sloughing, changes in sea cucumber behavior, and even increases in natural mortality and predation rates (Conand, 1991; Purcell et al., 2006). The use of passive inductive transponder (PIT) tags in sea cucumbers is also problematic because of the different results obtained with different sea cucumber 
species. Some studies have, for example, reported poor retention of PIT tags in 2 tropical sea cucumbers, $\mathrm{Ho}_{\text {- }}$ lothuria whitmaei and Actinopyga miliaris (Purcell et al., 2008). In fact, only $8 \mathrm{~d}$ after release in suitable reef habitats, just one-quarter of $H$. whitmaei individuals tagged by Purcell et al. (2008) retained PIT tags and no $A$. miliaris individuals retained them. Similar results were found for the gray sea cucumber (Holothuria grisea), where the retention of the PIT tag was low, with $100 \%$ being lost by week 9 (Rodríguez-Barreras et al., 2016), but in the case of Cucumaria frondosa, results on tag retention were much improved (Gianasi et al., 2015). Implanting the tag in an oral tentacle of C. frondosa to reach the hydrovascular system of the aquapharyngeal bulb resulted in the best retention rates in full-size individuals: from a maximum of $92 \%$ after $30 \mathrm{~d}$ to $68 \%$ at the end of the experimental period (300 d). Efficacy was lower in smaller individuals (84\% after $30 \mathrm{~d}$ and $42 \%$ after $300 \mathrm{~d}$ ).

In a pioneer work, Ebert (1978) studied growth of the sea cucumber known as the lolly fish (Holothuria atra) by tagging the plates of their calcareous rings with tetracycline. The growth of the plates was used to estimate growth parameters for the Brody-Bertalanffy growth equation. Subsequently, other methods based on weight and size data have been undertaken to study growth in both wild and cultured sea cucumber populations. For example, Battaglene et al. (1999) calculated sea cucumber length from wet weight measurements, using a polynomial regression. Measurements of specific growth rates and relative weight increase have also been obtained for sea cucumbers (Yang et al., 2005; Dong et al., 2008), while other studies have adapted different growth models like Francis's model and the von Bertalanffy model to calculate weight and length data (Conand, 1988; Herrero-Pérezrul et al., 1999; de la Fuente-Betancourt et al., 2001; Uthicke et al., 2004; Sulardiono and Prayitno, 2012). Interestingly, some consistent differences in growth rates have been observed between tropical species of sea cucumber, such as Stichopus vastus, the Florida sea cucumber (Holothuria floridana), the lolly fish, and the mammy fish (Actinopyga nobilis), exhibite slow growth rates (Ebert, 1978; de la Fuente-Betancourt et al., 2001; Uthicke et al., 2004; Sulardiono and Prayitno, 2012) and some temperate species, such as Australostichopus mollis and C. frondosa, that grow faster than the previously mentioned tropical species but also show some seasonal variation (Hamel and Mercier, 1996; Slater and Jeffs, 2010).

Holothuria (Rowethuria) arguinensis has a restricted distribution in the northeast Atlantic Ocean, from Portugal to the Canary Islands and Mauritania in northwestern Africa, although recently, it was recorded in the Southwestern Mediterranean Sea (Alicante, Spain) and in Algerian waters, implying that it is colonizing the Mediterranean Sea (González-Wangüemert and Borrero-Pérez, 2012; Mezali and Thandar, 2014). Holothuria arguinensis is one of the new target species of NE Atlantic and Southwestern Mediterranean fisheries, where catches driven by its high commercial value, are increasing (González-Wangüemert and Godino, 2016; González-Wangüemert et al., 2016; Roggatz et al., 2016). Illegal harvest of this species in Portugal and Spain, is a threat to the sustainability of the fishery, especially in the Ria Formosa lagoon, at Portimão and Albufeira (South Portugal), and at the coast of Cadiz (South Spain) (González-Wangüemert and Godino, 2016). Also, this species is targeted for aquaculture development for both commercial production and restocking (Domínguez-Godino et al., 2015).

The species has been linked to the presence of seaweed and seagrass meadows of Cymodocea nodosa and Zostera noltii, with reported densities up to 563 individuals/ha (Faro, South Portugal) (González-Wangüemert et al., 2013; Siegenthaler et al., 2015). The home range of $H$. arguinensis individuals has been estimated to average $35 \mathrm{~m}^{2}$, and individual movements are close to $10 \mathrm{~m} / \mathrm{d}$ (Siegenthaler et al., 2015).

An average size of $255 \mathrm{~mm}$ was reported for this species in Gran Canaria (Canary Islands, Spain) and a maximum size of $370 \mathrm{~mm}$ (Navarro et al., 2013). In Ria Formosa (South Portugal), González-Wangüemert et al. (2013) found individuals ranging between 70 to $360 \mathrm{~mm}$, and having an average size of $221 \mathrm{~mm}$ and a multimodal size-frequency distribution. Three years later, González-Wangüemert et al. (2016), considering $H$. arguinensis populations throughout the geographical range of this species, estimated a positive allometric growth. In that study, individuals ranged from 90 to $360 \mathrm{~mm}$ in length and had significant differences in mean size between sampled areas, such that individuals from Sagres (SW Portugal) were significantly longer than those from Ria Formosa.

Our aim was to obtain growth parameters from length-frequency data of the species $H$. arguinensis inhabiting the Ria Formosa (South Portugal), by fitting different growth models: the nonseasonal von Bertalanffy and the Hoenig seasonal von Bertalanffy models.

\section{Material and methods}

\section{Study area}

Ria Formosa is a coastal lagoon located in the Algarve region (South Portugal) (Fig. 1). Its area is approximately $105 \mathrm{~km}^{2}$, half of which is intertidal and covered by sand, mud and marshes (Duarte et al., 2007). It is composed of a system of barrier islands with small ponds, inlet deltas, and barrier platforms (Pacheco et al., 2010). The water temperature varies between $12^{\circ} \mathrm{C}$ and $13^{\circ} \mathrm{C}$ in winter and $27^{\circ} \mathrm{C}$ and $28^{\circ} \mathrm{C}$ in summer. Variations in salinity are small due to the low freshwater input into the lagoon, ranging between 35.5 and 36.9 throughout the year (Ribeiro et al., 2008), with the exception of surface waters for brief periods after heavy winter rainfall (Ribeiro et al., 2008; Rodrigues et al., 2015).

Ria Formosa, was declared a Natural Park in 1987 (Decreto-Lei No. 373/87, available from website) and it 


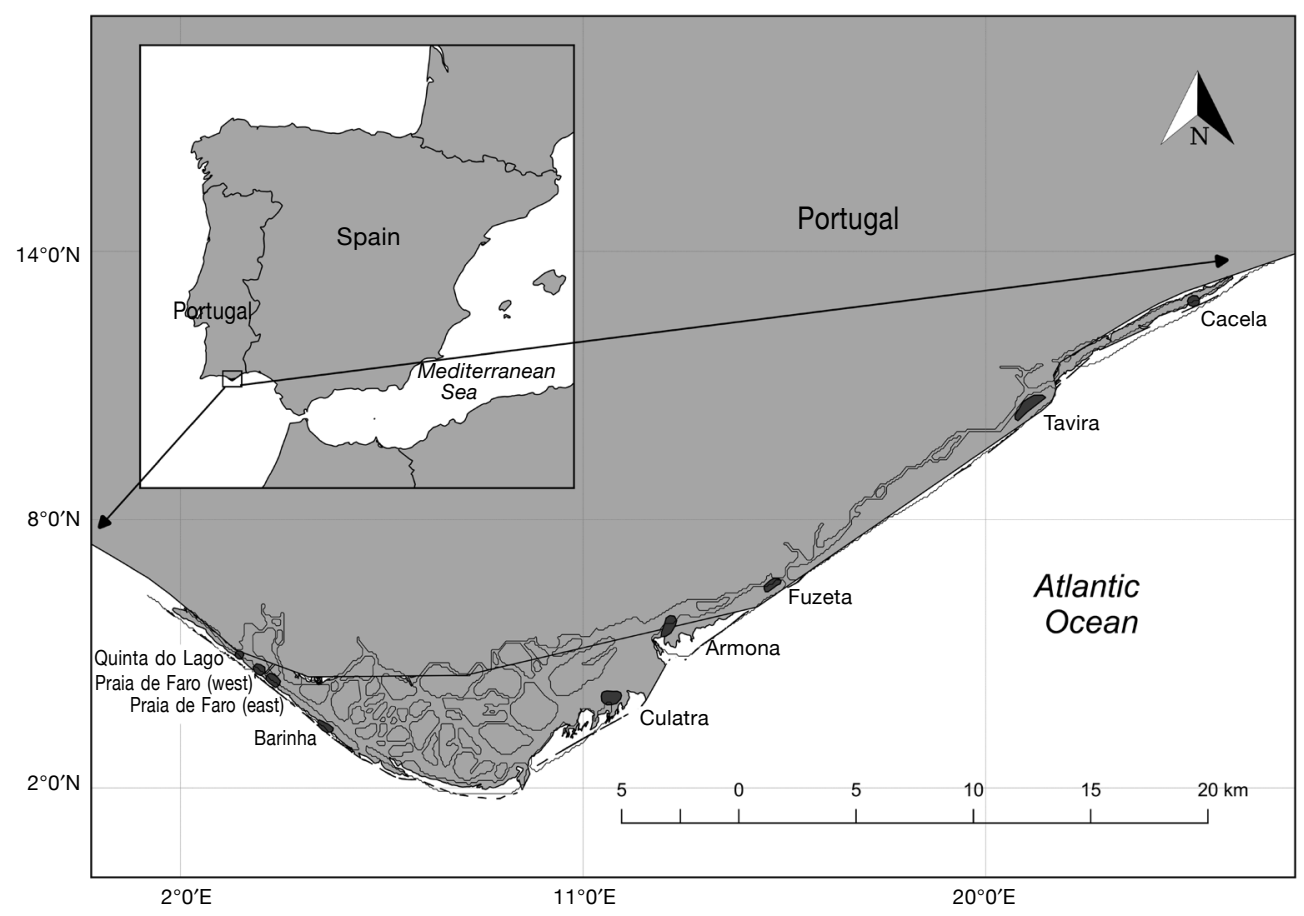

Figure 1

Map of the study area showing the 9 locations, indicated by areas shaded in black, where Holothuria arguinensis were sampled between November 2012 and March 2014 inside the Ria Formosa, a coastal lagoon in southern Portugal. Sampling was conducted by visual census at 3 sites: Praia de Faro to the west of the main bridge (PFW), Praia de Faro to the east of the main bridge (PFE), and Fuzeta (FUZ). Random sampling was conducted at 6 sites: Quinta do Lago (QTL), Barinha (BAR), CUL (Culatra), Armona (ARM), Tavira (TAV), and Cacela (CAC).

plays an important role in the local economy by supporting commercial fisheries, bait harvesting, tourism, aquaculture, port activities, and providing a recreational fishing area near human settlements. The lagoon is classified as coastal waters within the scope of the European Water Framework Directive (EC/2000/60, available from website).

\section{Data collection}

The data were collected by 2 methods: visual census and random sampling. During the volunteer program linked with the research project "Sea cucumbers: the new resources for a hungry fishery" (CUMFISH) conducted by the Centro de Ciências do Mar, Universidade do Algarve, monthly visual censuses of sea cucumbers were carried out in the Ria Formosa lagoon during low tides from November 2012 to March 2014 in 3 locations: 2 sites (west and east) at Praia do Faro and 1 site at Fuzeta (Fig. 1). In each locality, 6 transects (each $100 \times 2 \mathrm{~m}$ ) were surveyed. Three transects were surveyed by walking along the coast "outside" the water and 3 transects were surveyed by snorkeling "inside" sea water and by following the edge of the low tide level. All sea cucumber individuals were identified to species and their total length registered to the nearest $0.1 \mathrm{~cm}$. Measurements of length were recorded in situ without disturbing the animals, which were not touched or removed from the water. More details of the methods can be found in González-Wangüemert et al. (2013).The random sampling was conducted in 6 different locations inside the Ria Formosa-Quinta do Lago, Barinha, Armona, Tavira, Culatra, and Cacela (Fig. 1)-during February and March 2014. Presence (in absolute geographical coordinates [datum: World Geodetic System 1984]) and total length (in centimeters) of all sea cucumbers were recorded by 2 researchers walking along the intertidal zone during low tide and following a route with registered geographical coordinates. Again, sea cucumbers were measured in situ. In this way, it was possible to sample over a wide area and later to calculate the area sampled. The sampling was undertaken during tides lower than $0.7 \mathrm{~m}$, when the seagrass meadows were always exposed in the sampling locations.

\section{Data analysis}

All length data obtained from visual census and random sampling were pooled together and grouped in $4-\mathrm{cm}$ classes. Two different growth models-the non- 


\section{Table 1}

Number and mean lengths (with standard deviations [SD]) for individuals of the sea cucumber Holothuria arguinensis sampled by visual census and random sampling inside the Ria Formosa, a coastal lagoon in southern Portugal, between November 2012 and March 2014. The 9 localities sampled (see Fig. 1) were Armona (ARM), Barinha (BAR), Cacela (CAC), Culatra (CUL), Fuzeta (FUZ), Praia de Faro to the west of the main bridge (PFW), Praia de Faro to the east of the main bridge (PFE), Quinta do Lago (QTL), and Tavira (TAV). N signifies number of sampled individuals.

\begin{tabular}{lrcrrr}
\hline Locality & $\mathrm{N}$ & $\begin{array}{c}\text { Mean length } \\
(\mathrm{cm})\end{array}$ & $\mathrm{SD}$ & $\begin{array}{c}\text { Minimum } \\
(\mathrm{cm})\end{array}$ & $\begin{array}{c}\text { Maximum } \\
(\mathrm{cm})\end{array}$ \\
\hline ARM & 222 & 26.51 & 6.42 & 10.00 & 45.00 \\
BAR & 78 & 17.54 & 3.31 & 12.00 & 23.00 \\
CAC & 1 & 23.00 & - & 23.00 & 23.00 \\
CUL & 12 & 23.42 & 5.47 & 13.00 & 34.00 \\
FUZ & 78 & 23.38 & 6.29 & 10.00 & 38.00 \\
PFE & 433 & 22.46 & 6.27 & 4.00 & 35.00 \\
PFW & 332 & 21.63 & 5.18 & 10.00 & 48.00 \\
QTL & 25 & 17.48 & 4.78 & 15.00 & 25.00 \\
TAV & 17 & 17.18 & 6.27 & 9.00 & 30.00 \\
Total & 1198 & 23.10 & 6.28 & 4.00 & 48.00 \\
& & & & & \\
\hline
\end{tabular}

seasonal von Bertalanffy growth model (Pauly, 1987) and the Hoenig seasonal von Bertalanffy model (Hoenig and Hanumara, 1982)—were fitted to the lengthfrequency data by using the electronic length frequency analysis (ELEFAN) system implemented in the length frequency distribution analysis (LFDA) software, vers. 5.0 (Kirkwood $^{1}$ ). The best estimators of asymptotic length $\left(L_{\infty}\right)$ and the growth coefficient $(K)$ were selected on the basis of maximum value of the score function and the best fit of the curve to the observed data (Kirkwood $^{1}$ ).

The ELEFAN method is based on fitting the von Bertalanffy model to length- frequency data (Pauly, 1987). It works by restructuring the length-frequency data, emphasizing the peaks and troughs in the data set, and calculating score functions for growth curves generated for different combinations of von Bertalanffy growth parameters. Every time the growth curves passed through the peaks in the restructured data it accumulates points, resulting in a score function for each curve. The Hoenig function takes into account seasonality in growth, including a parameter that fits the beginning of the sinusoidal function ( $T s)$, and the parameter $C$ that expresses the relative amplitude of the seasonal oscillation in growth (Pauly et al., 1992).

\section{Results}

Length data of 1198 individuals of $H$. arguinensis from 9 different localities inside the Ria Formosa were used for length-frequency analysis (Table 1).

\footnotetext{
${ }^{1}$ Kirkwood, G. 2001. Enhancement and support of computer aids for fisheries management. Final technical report, 65 p. MRAG, Ltd., London. [Available from website.]
}

For the nonseasonal growth model, estimates of $K=1.99$ and $L_{\infty}=40 \mathrm{~cm}$ were obtained with a score function of 0.460 . However, the growth curve does not adequately fit the data (Suppl. Fig.).

Considering these results, we then fitted the Hoenig model for seasonal growth. This provided estimates of $K=0.88$ and $L_{\infty}=69.9 \mathrm{~cm}$, and a score function of 0.565 . The average length was $23.1 \mathrm{~cm}$, sizes ranged from 4 to $48 \mathrm{~cm}$, and approximately $98 \%$ of the individuals ranged from 11 to $35 \mathrm{~cm}$ (Fig. 2). The growth curve showed a higher score function than that of the nonseasonal growth model (Fig. 3). The value of $C=1$ indicates the existence of a period of no growth during the year for the species.

\section{Discussion}

The $L_{\infty}$ and $K$ for $H$. arguinensis were estimated by using 2 different functions. The first function, the nonseasonal von Bertalanffy model, did not provide realistic results. However, when seasonality was included (with the Hoenig model), more reliable values were obtained, which confirmed the seasonality in the growth of $H$. arguinensis. The observed growth rate $(K=0.88)$ indicates that this species achieves asymptotic size quickly, even faster than tropical commercially valuable holothurians, such as the lolly fish $(K=0.11)$, Thelenota ananas $(K=0.20)$, Stichopus chloronotus $(K=0.45)$, or Isostichopus fuscus ( $K=0.18$ ) (Ebert, 1978; Conand, 1988; Herrero-Pérezrul et al., 1999). Herrero-Pérezrul et al. (1999) discussed the difficulties of comparing growth parameters derived from von Bertalanffy-like models of different sea cucumbers species because not all model assumptions are fulfilled. The 3 general assumptions 


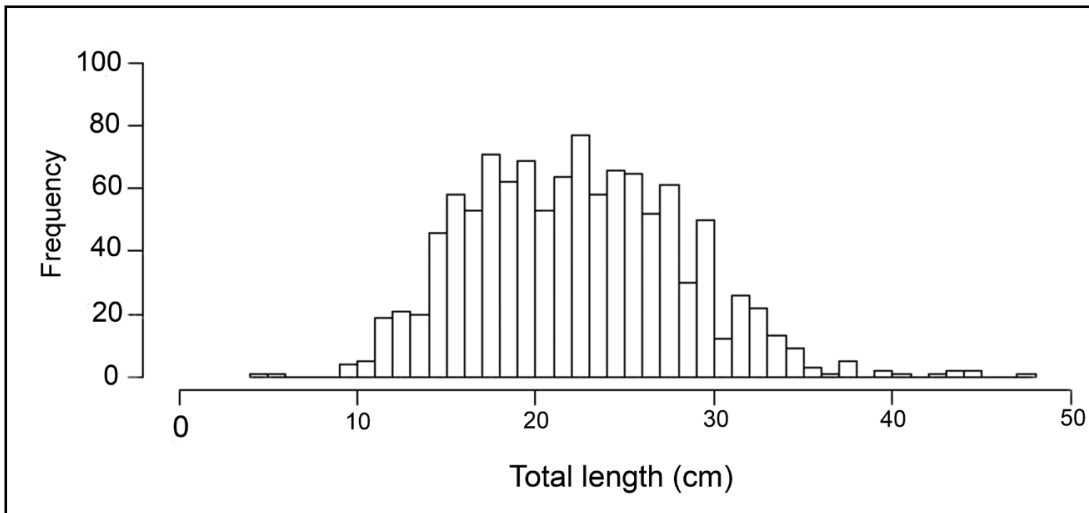

Figure 2

Length-frequency distribution of Holothuria arguinensis sampled inside the Ria Formosa lagoon in southern Portugal between November 2012 and March 2014.

for these models are the following: 1) species reproduce and recruit once per year; 2) species reach a specific size; and 3) species grow isometrically. Most commercial sea cucumber species fulfill the first 2 assumptions, but usually they do not exhibit isometric growth. In the case of $H$. arguinensis, allometric growth has also been reported (González-Wangüemert et al., 2016). For this reason, comparisons of growth rates from different commercial species must be regarded with cau- tion; most of them do not show the isometric growth assumed by the model.

Faster growth rates may have important and positive effects on the survival of a species, primarily under high stress conditions and in disturbed environments (Morgan, 2012). Achieving a larger size rapidly could be an adaptive advantage: larger sea cucumbers would be capable of moving and stabilizing themselves in more mobile sediments, such as sandy substrates, and

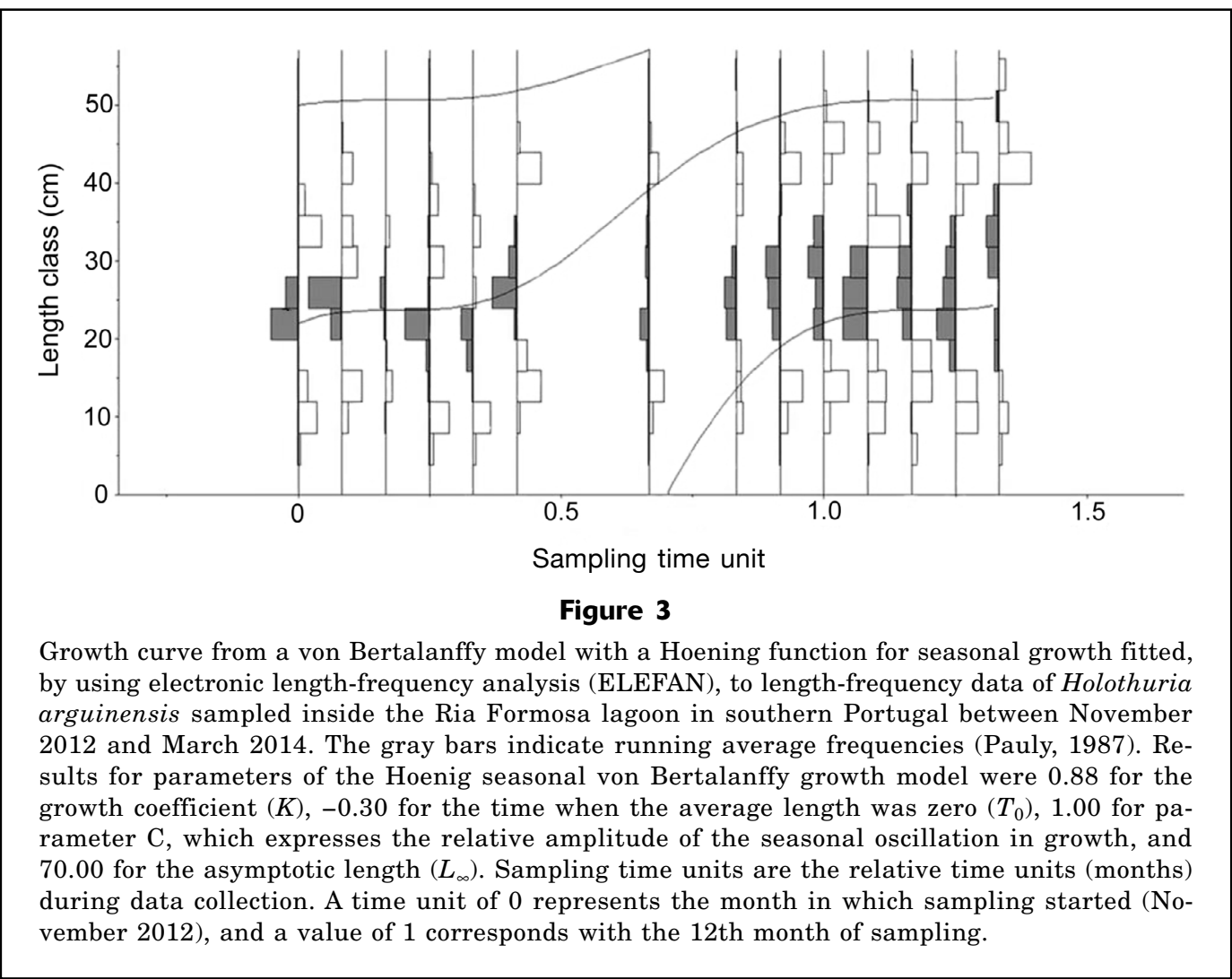


they would also be more likely to escape predation (Wiedemeyer, 1993). In the Salomon Islands, the growth rate, as well as the daily distance covered by the sand fish (Holothuria scabra), was found to be related to substrate type, and the sandy areas were occupied only when individuals reached a specific size (Mercier et al., 2000). Inside the Ria Formosa, individuals of $H$. arguinensis move through a patchy environment; despite the relatively large percent coverage of $Z$. noltii $(46 \%$ of the intertidal area) within the Ria Formosa, distribution of this seagrass species is highly fragmented, dominated by small patches from 0 to 5 ha (Guimarães et al., 2012). These seagrass patches are separated by sand, mud, and marshes that sea cucumbers must pass through when searching for more suitable feeding areas, or probably for areas where they can avoid direct sunlight and desiccation (González-Wangüemert et al., 2013). However, the results obtained by Siegenthaler et al. (2015) in a small-scale capture-recapture experiment with $H$. arguinensis in the Ria Formosa, revealed that mean length was not a significant factor in determining the distribution of this species, and its movement was independent of habitat type (sand and seagrass). In fact, movement of $H$. arguinensis was better explained by the need of specimens for shelter against UV-radiation, when individuals remain outside water during low tides (Siegenthaler et al., 2015). Further studies should be considered to evaluate whether the same pattern exists at larger spatial and temporal scales than those considered by Siegenthaler et al. (2015), and also including a greater size range of animals for the experiment.

A faster growth rate could also be the result of a decrease in predation rate, mainly during the early life history stages. Although few predators are known to feed on sea cucumbers, several antipredation mechanisms has been described for holothurians (Francour, 1997) and some of these mechanisms seems to be linked to animal size. For example, in the lolly fish, the strength of the toxin present on its skin significantly increases with the size of an individual (Castillo ${ }^{2}$.

On the other hand, the high growth rates of $H$. arguinensis in the Ria Formosa could be linked to the high productivity of this ecosystem, where a rich phytobenthos, of macrophytic and microphytic organisms (seagrass and diatoms) is located (Brito et al., 2009). In some mesoscosm experiments carried out on the Great Barrier Reef in Australia with lolly fish, it was found that higher food availability per individual increased growth rate (Lee et al., 2008). Therefore, further studies of individuals from areas outside Ria Formosa, and with varying levels of natural productivity, should be carried out to confirm the growth rates we have reported here.

\footnotetext{
${ }^{2}$ Castillo, J. A. 2006. Predator defense mechanisms in shallow water sea cucumbers (Holothuroidea). UCB Moorea Class: Biol. Geomorphol. Trop. Isl., Univ. Calif. Berkeley, Berkeley, CA. [Available from website.]
}

The value obtained for the parameter $C$ (Hoenig model) indicates a seasonal cycle of growth for $H$. arguinensis, which may cease at least during part of the year. According to Pauly (1987), $T s+0.5$ is the time of the year when growth is slower, and where $T s$ denotes the beginning of the sinusoidal growth oscillation. This winter point, suggests a reduction in the growth rate of $H$. arguinensis at 0.19 time units (the time unit for this study was a month, where a 0 time unit represents the month in which the sampling started [November 2012] and 1 time unit corresponds to the 12th month of sampling) from the beginning of the sampling year, which coincides with the months of January and February, when waters may have brackish conditions and the lowest temperatures occur in Ria Formosa (Newton and Mudge, 2003). Feeding experiments on $H$. arguinensis, in laboratory tanks, could confirm this reduction in growth rate during winter months because under rearing conditions, the species is stationary and decreases feeding rate when water temperature is lower than $14^{\circ} \mathrm{C}$ (Domínguez-Godino and González-Wangüemert ${ }^{3}$ ). These low temperatures are common during winter months in Ria Formosa (Ramos et al., 2013). Another temperate sea cucumber species inhabiting the Aegean Sea, Holothuria tubulosa, exhibits similar behavior, with a negative specific growth rate at $15^{\circ} \mathrm{C}$. At this temperature, individuals enter a hibernation phase and have a corresponding drop in metabolic rate, which directly affects their feeding activity (Günay et al., 2015).

This pattern of a complete shutdown in growth during winter is also found in other temperate species such as A. mollis (Morgan, 2012), C. frondosa (Hamel and Mercier, 1996), Parastichopus californicus (Paltzat et al., 2008) and Holothuria theeli (Sonnenholzner, 2003). Sea cucumbers, seem to have failed to adapt to large fluctuations in water temperature (Dong et al., 2008), clearly showing an optimal temperature for growth which is close to the optimal temperature for food intake (Yang et al., 2005). Conversely, high water temperatures can also induce aestivation in some sea cucumber species, such as has been observed in Apostichopus japonicus and Australostichopus mollis (Yang et al., 2005). These results show that water temperature has an effect on the physiological performance of sea cucumbers and that their growth is largely influenced by environmental conditions and food supply (Hamel and Mercier, 1996; Sonnenholzner, 2003).

\section{Acknowledgments}

This research was supported by the CUMFISH (PTDC/ MAR/119363/2010) and "Sea cucumber as new marine resource: potential for aquaculture" (CUMARSUR) (PTDC/MAR-BIO/5948/2014) projects funded by Funda-

\footnotetext{
${ }^{3}$ Domínguez-Godino, J., and M. González-Wangüemert. In review. Centro de Ciências do Mar, Universidade do Algarve, Campus de Gambelas, 8005-139 Faro, Portugal.
} 
ção para a Ciência e a Tecnologia (FCT, Portugal), and was performed as a dissertation for the International Master in Marine Biodiversity and Conservation. Authors thank the field support of all volunteers implementing and carrying out the visual censuses. The first author was supported by Fundación para el Futuro de Colombia (Colfuturo) and M. González-Wangüemert by FCT Investigator Programme-Career Development (IF/00998/2014).

\section{Literature cited}

Battaglene, S. C., J. E. Seymour, and C. Ramofafia. 1999. Survival and growth of cultured juvenile sea cucumbers, Holothuria scabra. Aquaculture 178:293-322. Article

Brito, A., A. Newton, P. Tett, and T. F. Fernandes. 2009. Temporal and spatial variability of microphytobenthos in a shallow lagoon: Ria Formosa (Portugal). Est. Coast. Shelf Sci. 83:67-76. Article

Bruckner, A. W. (ed.)

2006. Proceedings of the CITES workshop on the conservation of sea cucumbers in the families Holothuriidae and Stichopodidae. NOAA Tech. Memo. NMFS-OPR-34, $244 \mathrm{p}$.

Conand, C.

1983. Methods of studying growth in holothurians (bechede-mer), and preliminary results from a beche-de-mer tagging experiment in New Caledonia. SPC Fish. Newsl. 26:31-38

1988. Comparison between estimations of growth and mortality of two stichopodid holothurians: Thelenota ananas and Stichopus chloronotus (Echinodermata: Holothuroidea). In Proceedings of the $6^{\text {th }}$ International Coral Reef Symposium, vol. 2; Townsville, Australia, 8-12 August (J. H. Choat and D. Barnes, eds.), p. 661-665. $6^{\text {th }}$ Int. Coral Reef Symp. Exec. Comm., Townsville, Australia.

1991. Long-term movements and mortality of some tropical sea-cucumbers monitored by tagging and recapture. In Biology of Echinodermata: Proceedings of the $7^{\text {th }}$ International Echinoderm Conference; Atami, Japan, 9-14 September 1990 (T. Yanagisawa I. Yasumasu, C. Oguro, N. Suzuki, and T. Motokawa, eds.), p. 169-175.. A.A. Balkema Publishers, Rotterdam, Netherlands.

de la Fuente-Betancourt, M. G., A. de Jesús-Navarrete, E. Sosa-Cordero, and M. D. Herrero-Perezrul.

2001. Assessment of the sea cucumber (Echinodermata: Holothuroidea) as potential fishery resource in Banco Chinchorro, Quintana roo, Mexico. Bull. Mar. Sci. 68:59-67.

Domínguez-Godino, J. A., M. J. Slater, C. Hannon, and M. González-Wangüermert.

2015. A new species for sea cucumber ranching and aquaculture: breeding and rearing of Holothuria arguinensis. Aquaculture 438:122-128. Article

Dong, Y., S. Dong, and T. Ji.

2008. Effect of different thermal regimes on growth and physiological performance of the sea cucumber Apostichopus japonicus Selenka. Aquaculture 275:329-334. Article

Duarte, P., B. Azevedo, C., Ribeiro, A., Pereira, M., Falcão, D., Serpa R. Bandeira, and J. Reia.

2007. Management oriented mathematical modelling of Ria Formosa (South Portugal). Transitional Waters Monogr. 1:13-51. Article
Ebert, T. A.

1978. Growth and size of the tropical sea cucumber Holothuria (Halodeima) atra Jager at Enewetak Atoll, Marshall Islands. Pac. Sci. 32:183-191.

Eriksson, H., M. de la Torre Castro, and P. Olsson.

2012. Mobility, expansion and management of a multi-species scuba diving fishery in East Africa. PLoS ONE 7(4): e35504. Article

Francour, P.

1997. Predation on holothurians: a literature review. Invertebr. Biol. 116:52-60. Article

Gianasi, B. L., K. Verkaik, J.-F. Hamel, and A. Mercier.

2015. Novel use of PIT tags in sea cucumbers: promising results with the commercial species Cucumaria frondosa. PLoS ONE 10(5):e0127884. Article

González-Wangüemert, M., and G. Borrero-Pérez.

2012. A new record of Holothuria arguinensis colonizing the Mediterranean Sea. Mar. Biodivers. Rec. 5:e105. Article

González-Wangüemert, M., and J. A. D. Godino.

2016. Sea cucumbers as new marine resource in Europe. Front. Mar. Sci. Conf. Abstr.: IMMR I International Meeting on Marine Research 2016. Article

González-Wangüemert, M., T. Braga, M. Silva, S. Valente, F. Rodriguez, and E. Serrao.

2013. Volunteer programme assesses the Holothuria arguinensis populations in Ria Formosa (southern Portugal). SPC Beche-de-mer Inf. Bull. 33:44-48.

González-Wangüemert, M., M. Aydin, and C. Chantal.

2014. Assessment of sea cucumber populations from the Aegean Sea (Turkey): first insights to sustainable management of new fisheries. Ocean Coast. Manage. 92:87-94. Article

González-Wangüemert, M., S. Valente, and M. Aydin.

2015. Effects of fishery protection on biometry and genetic structure of two target sea cucumber species from the Mediterranean Sea. Hydrobiologia 743:65-74. Article

González-Wangüemert, M., S. Valente, F. Henriques, J. A. Domínguez-Godino, and E. A. Serrão.

2016. Setting preliminary biometric baselines for new target sea cucumbers species of the NE Atlantic and Mediterranean fisheries. Fish. Res. 179:57-66. Article

Guimarães, M. H. M. E., A. H. Cunha, R. L. Nzinga, and J. F. Marques.

2012. The distribution of seagrass (Zostera noltii) in the Ria Formosa lagoon system and the implications of clam farming on its conservation. J. Nat. Conserv. 20:30-40. Article

Günay, D., D. Emiroğlu, T. Tolon, O. Özden, and H. Saygi.

2015. Growth and survival rate of juvenile sea cucumbers (Holothuria tubulosa, Gmelin, 1788) at various temperatures. Turkish J. Fish. Aquat. Sci. 15:533-541. Article

Hamel, J.-F. and A. Mercier.

1996. Early development, settlement, growth, and spatial distribution of the sea cucumber Cucumaria frondosa (Echinodermata: Holothuroidea). Can. J. Fish. Aquat. Sci. 53:253-271. Article

Herrero-Pérezrul, M. D., H. Reyes Bonilla, F. García-domínguez, and C. Cintra-Buenrostro.

1999. Reproduction and growth of Isostichopus fuscus (Echinodermata:Holothuroidea) in the southern Gulf of California, México. Mar. Biol. 135:521-532. Article

Hoenig, J. M., and R. C. Hanumara.

1982. A statistical study of a seasonal growth model for fishes, 91 p. Tech. Rep., Dep. Comp. Sci. Stat., Univ. Rhode Isl., Narragansett, RI. 
Lee, J., M. Byrne, and S. Uthicke.

2008. The influence of population density on fission and growth of Holothuria atra in natural mesocosms. J. Exp. Mar. Biol. Ecol. 365:126-135. Article

Lovatelli, A., C. Conand, S. Purcell, S. Uthicke, J.-F. Hamel, and A. Mercier (eds.).

2004. Advances in sea cucumber aquaculture and management. FAO Fish. Tech. Pap. 463, 425 p. FAO, Rome.

Mercier, A., S. C. Battaglene, and J.-F. Hamel.

2000. Periodic movement, recruitment and size-related distribution of the sea cucumber Holothuria scabra in Solomon Islands. Hydrobiologia 440:81-100. Article

Mezali, K., and A. S. Thandar.

2014. First record of Holothuria (Roweothuria) arguinensis (Echinodermata: Holothuroidea: Aspidochirotida: Holothuriidae) from the Algerian coastal waters. Mar. Biodivers. Rec. 7:e40. Article

Morgan, A. D.

2012. Use of a growth model to estimate size at age in the temperate sea cucumber Australostichopus mollis. SPC Beche-de-mer Inf. Bull. 32:24-32.

Navarro, P. G., S. García-Sanz, and F. Tuya.

2013. Patrones de abundancia y talla de Holothuria sanctori, Holothuria mammata y Holothuria arguinensis (Echinodermata: Holoturoidea) en la isla de Gran Canaria, Atlántico oriental. Rev. Biol. Mar. Oceanogr. 48:273-284. Article

Newton, A., and S. M. Mudge.

2003. Temperature and salinity regimes in a shallow, mesotidal lagoon, the Ria Formosa, Portugal. Est. Coast. Shelf Sci. 57:73-85. Article

Pacheco, A., Ó. Ferreira, J. J. Williams, E. Garel, A. Vila-Concejo, and J. A. Dias.

2010. Hydrodynamics and equilibrium of a multiple-inlet system. Mar. Geol. 274:32-42. Article

Paltzat, D. L., C. M. Pearce, P. A. Barnes, and R. S. McKinley. 2008. Growth and production of California sea cucumbers (Parastichopus californicus Stimpson) co-cultured with suspended Pacific oysters (Crassostrea gigas Thunberg). Aquaculture 275:124-137. Article

Pauly, D.

1987. A review of the ELEFAN system for analysis of length-frequency data in fish and aquatic invertebrates. In Length-based methods in fisheries research. ICLARM Conf. Proc. 13 (D. Pauly and G. R. Morgan, eds.), p. 7-34. Int. Cent. Living Aquat. Resour. Manage., Manila, Philippines, and Inst. Sci. Res., Safat, Kuwait.

Pauly, D., M. Soriano-Bartz, J. Moreau, and A. JarreTeichmann.

1992. A new model accounting for seasonal cessation of growth in fishes. Aust. J. Mar. Freshw. Res. 43:1151-1156. Article

Purcell, S. W.

2010. Managing sea cucumber fisheries with an ecosystem approach. FAO Fish. Aquacult. Tech. Pap. 520, 157 p. FAO, Rome.

Purcell, S. W., B. F. Blockmans, and W. J. Nash.

2006. Efficacy of chemical markers and physical tags for large-scale release of an exploited holothurian. J. Exp. Mar. Biol. Ecol. 334:283-293. Article

Purcell, S. W., N. S. Agudo, and H. Gossuin.

2008. Poor retention of passive induced transponder (PIT) tags for mark-recapture studies on tropical sea cucumbers. SPC Beche-de-mer Inf. Bull. 28:53-55.

Purcell, S. W., Y. Samyn, and C. Conand.

2012. Commercially important sea cucumbers of the world. FAO Species Catalogue for Fishery Purposes 6, 150 p. FAO, Rome.

Purcell, S. W., A. Mercier, C. Conand, J.-F. Hamel, M. V. Toral-Granda, A. Lovatelli, and S. Uthicke.

2013. Sea cucumber fisheries: global analysis of stocks, management measures and drivers of overfishing. Fish Fish. 14:34-59. Article

Ramos, J. A., P. Pedro, A. Matos, and V. H. Paiva.

2013. Relation between climatic factors, diet and reproductive parameters of Little Terns over a decade. Acta Oecol. 53:56-62. Article

Ribeiro, J., C. C. Monteiro, P. Monteiro, L. Bentes, R. Coelho, J. M. S. Gonçalves, P. G. Lino, and K. Erzini.

2008. Long-term changes in fish communities of the Ria Formosa coastal lagoon (southern Portugal) based on two studies made 20 years apart. Est. Coast. Shelf Sci. 76:57-68. Article

Rodrigues, F., S. Valente, and M. González-Wangüemert.

2015. Genetic diversity across geographical scales in marine coastal ecosystems: Holothuria arguinensis a model species. J. Exp. Mar. Biol. Ecol. 463:158-167. Article

Rodríguez-Barreras, R., J. López-Morell, and A. M. Sabat.

2016. Effectiveness of two tagging devices in the sea cucumber Holothuria (Halodeima) grisea. Mar. Freshw. Res. 68:563-567. Article

Roggatz, C. C., M. González-Wangüemert, H. Pereira, M. J. Rodrigues, M. M. da Silva, L. Barreira, J. Varela, and L. Custódio.

2016. First report of the nutritional profile and antioxidant potential of Holothuria arguinensis, a new resource for aquaculture in Europe. Nat. Prod. Res. J. 30:2034-2040. Article

Siegenthaler, A., F. Cánovas, and M. González-Wangüemert.

2015. Spatial distribution patterns and movements of $\mathrm{Ho}$ lothuria arguinensis in the Ria Formosa (Portugal). J. Sea Res. 102:33-40. Article

Slater, M. J., and A. G. Jeffs.

2010. Do benthic sediment characteristics explain the distribution of juveniles of the deposit-feeding sea cucumber Australostichopus mollis? J. Sea Res. 64:241-249. Article

Sonnenholzner, J.

2003. Seasonal variation in the food composition of $\mathrm{Ho}$ lothuria theeli (Holothuroidea: Aspidochirotida) with observations on density and distribution patterns at the central coast of Ecuador. Bull. Mar. Sci. 73:527-543.

Sulardiono, B., S. B. Prayitno, and I. B. Hendrarto.

2012. The growth analysis of Stichopus vastus (Echinodermata: Stichopodidae) in Karimunjawa waters. J. Coast. Dev. 15:315-323.

Uthicke, S., D. Welch, and J. A. H. Benzie.

2004. Slow growth and lack of recovery in overfished holothurians on the Great Barrier Reef: evidence from DNA fingerprints and repeated large-scale surveys. Conserv. Biol. 18:1395-1404. Article

Wiedemeyer, W. L.

1993. Feeding behavior of two tropical Holothurians Holothuria (Metriatyla) scabra (Jager 1833) and H. (Halodeima) atra (Jager 1833), from Okinawa, Japan. In Proceedings of the $7^{\text {th }}$ International Coral Reef Symposium, vol. 2; Guam, 22-27 June 1992 (R. H. Richmond, ed.), p. 853-860. Univ. Guam Press, Mangilao, Guam.

Yang, H., X. Yuan, Y. Zhou, Y. Mao, T. Zhang, and Y. Liu.

2005. Effects of body size and water temperature on food consumption and growth in the sea cucumber Apostichopus japonicus (Selenka) with special reference to aestivation. Aquacult. Res. 36:1085-1092. Article 